\title{
Conkunitzin-S1 Is the First Member of a New Kunitz-type Neurotoxin Family
}

\author{
STRUCTURAL AND FUNCTIONAL CHARACTERIZATION*[S
}

Received for publication, February 16, 2005, and in revised form, April 14, 2005 Published, JBC Papers in Press, April 15, 2005, DOI 10.1074/jbc.C500064200

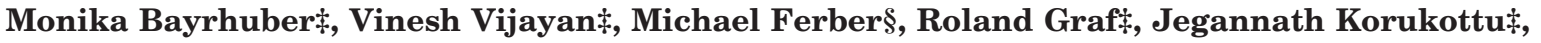
Julita Imperialn, James E. Garrett|, Baldomero M. Oliveraף, Heinrich Terlau§**, Markus Zweckstetter $\$$ \$ , and Stefan Becker $\$ \S \S$
\end{abstract}

From the $\ddagger$ Department for NMR-based Structural Biology, Max-Planck-Institute for Biophysical Chemistry, Am Fassberg 11, 37077 Göttingen, Germany, the §Molecular and Cellular Neuropharmacology Group, Max-Planck-Institute for Experimental Medicine, Hermann-Rein-Strasse 3, 37075 Göttingen, Germany, the 1 Department of Biology, University of Utah, Salt Lake City, Utah 84112, and \|Cognetix, Inc., Salt Lake City, Utah 84108

\begin{abstract}
Conkunitzin-S1 (Conk-S1) is a 60-residue neurotoxin from the venom of the cone snail Conus striatus that interacts with voltage-gated potassium channels. Conk-S1 shares sequence homology with Kunitz-type proteins but contains only two out of the three highly conserved cysteine bridges, which are typically found in these small, basic protein modules. In this study the three-dimensional structure of Conk-S1 has been solved by multidimensional NMR spectroscopy. The solution structure of recombinant Conk-S1 shows that a Kunitz fold is present, even though one of the highly conserved disulfide cross-links is missing. Introduction of a third, homologous disulfide bond into Conk-S1 results in a functional toxin with similar affinity for Shaker potassium channels. The affinity of Conk-S1 can be enhanced by a pore mutation within the Shaker channel pore indicating an interaction of Conk-S1 with the vestibule of potassium channels.
\end{abstract}

Kunitz domain proteins, like the bovine pancreatic trypsin inhibitor (BPTI) ${ }^{1}(1)$ or the dendrotoxins (2) are small, basic proteins that contain three highly conserved disulfide bonds. The three disulfide cross-links make these extracellular proteins extremely stable. Two different general functions are

* The costs of publication of this article were defrayed in part by the payment of page charges. This article must therefore be hereby marked "advertisement" in accordance with 18 U.S.C. Section 1734 solely to indicate this fact.

S The on-line version of this article (available at http://www.jbc.org) contains supplemental Table 1 .

The atomic coordinates and structure factors (code 1YL2 (for ConkS1)) have been deposited in the Protein Data Bank, Research Collaboratory for Structural Bioinformatics, Rutgers University, New Brunswick, NJ (http://www.rcsb.org/).

The NMR assignments were deposited in the BioMagResBank (accession no. 6505).

** Supported by the Biofuture Prize of the German Ministry of Education and Research (Förderkennzeichen 031 1859).

fecipient of a Deutsche Forschungsgemeinschaft Emmy NoetherFellowship (ZW71/1-4). To whom correspondence may be addressed. Tel.: 49-551-201-2220; Fax: 49-551-201-2202; E-mail: mzwecks@ gwdg.de.

$\S \S$ To whom correspondence may be addressed. Tel.: 49-551-2012222; Fax: 49-551-201-2202; E-mail: sabe@nmr.mpibpc.mpg.de.

1 The abbreviations used are: BPTI, bovine pancreatic trypsin inhibitor; Conk-S1, conkunitzin-S1; Conk-S1 ${ }^{\mathrm{CC}}$, conkunitzin-S1 G16C,Q40C; NOE, nuclear overhauser effect; NOESY, nuclear overhauser effect spectroscopy; Shaker- $\Delta 6-46$, Shaker potassium channel with removed $\mathrm{N}$-terminal inactivation domain; r.m.s.d., root mean square deviation. known for the different Kunitz proteins. One group, including BPTI, consists of potent protease inhibitors. The complex of BPTI and trypsin is exceptionally stable, with an association constant $>10^{13} \mathrm{M}^{-1}(3)$. The dendrotoxins belong to another group of Kunitz peptides found in the venom of the black mamba, which block different potassium channels with a high degree of specificity and selectivity (4). In snake and scorpion venoms a diverse set of different potassium channel blockers have been characterized (2).

Despite the great variety of toxins from the venoms of the predatory cone snails, relatively few have been identified so far that interact with potassium channels (5). Most conotoxins are small, peptidic toxins that typically contain 10-30 amino acids and bind with high affinity and specificity to various ligand- or voltage-gated ion channels. One striking feature of these peptides is that they usually contain a diverse complement of posttranslational modifications, like $\mathrm{C}$-terminal amidation, hydroxyprolines, or glycosylation of serine or threonine (6). Conotoxins can be broadly divided into two groups, the non-disulfide-rich peptides and the disulfide-rich conotoxins. The latter conotoxins are further separated into several families based on cysteine bridge pattern and biological activities (5).

The potassium channel-targeted toxin conkunitzin-S1 (Conk-S1) from the venom of Conus striatus is the first member of a new family of polypeptides. Recently it has been shown that Conk-S1 blocks Shaker potassium channels with an $\mathrm{IC}_{50}$ of less than 100 nM. $^{2}$ Compared with most toxins from Conus venoms, Conk-S1 is unusually long (60 amino acids). The only post-translational modification of this peptide is the amidation of the C-terminal carboxylic acid. Conk-S1 shares $33 \%$ sequence identity with BPTI and $35 \%$ with dendrotoxin I, indicating that it belongs to the Kunitz domain family of proteins (see Table I). Therefore we do not use the term "conotoxin" for Conk-S1, which is restricted to smaller disulfide-rich peptide toxins from cone snails.

One striking difference between Conk-S1 and other native Kunitz-type proteins is that it contains only four cysteine residues, resulting in only two disulfide bridges instead of the three found in all other native proteins that have been biochemically characterized in this group. The homologous cysteine residues of BPTI and dendrotoxin I are replaced by Gly ${ }^{16}$ and $\mathrm{Gln}^{40}$ of Conk-S1. Therefore, Conk-S1 is a Kunitz domain protein in which one of the highly conserved disulfide bridges is missing.

${ }^{2}$ J. S. Imperial, N. Silverton, B. M. Olivera, P. K. Bandyopadhyay, A. Sporning, M. Ferber, and H. Terlau, submitted for publication. 
TABLE I

Amino acid sequence of Conk-S1 and alignment with selected Kunitz domain proteins (30).

BPTI is the bovine pancreatic trypsin inhibitor (30); DTI and DTK are dendrotoxin I and K, respectively, from Dendroaspis polylepsis polylepsis

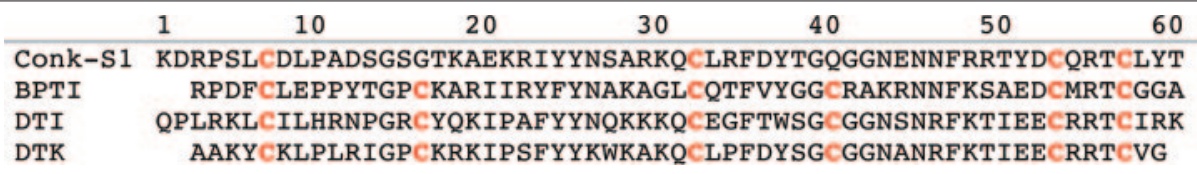

Here we present the NMR-derived solution structure of recombinant Conk-S1; these data demonstrate that structurally, Conk-S1 is a Kunitz domain protein. We show that the heterologously expressed peptide with a free carboxylic acid at the $\mathrm{C}$ terminus is fully functional compared with the natural amidated form of Conk-S1. Conk-S1 represents the first threedimensional structure of a native Kunitz-type protein with only two disulfide bonds. To evaluate the functional importance of the "missing" third disulfide bond, these cysteine residues have been introduced into Conk-S1. The functional data obtained indicate that this third disulfide bond does not affect the biological function of Conk-S1, i.e. blocking of its target potassium channel.

\section{MATERIALS AND METHODS}

Protein Preparation-Conk-S1 and Conk-S1 with an additional C-C bridge, Conk-S1 ${ }^{\mathrm{CC}}$, were expressed in Escherichia coli as insoluble intein fusion proteins. The inclusion bodies were dissolved in $6 \mathrm{M}$ guanidinium hydrochloride and refolded by removal of the denaturant via dialysis. After intein cleavage triggered by a $\mathrm{pH}$ change (7) the released peptides were further purified by high performance liquid chromatography.

Mass Spectrometry -For electrospray quadrupole mass spectrometry the source capillary was set to $2.94 \mathrm{kV}$. Scans were acquired in positiveion mode at $\mathrm{m} / \mathrm{z} 500-2500$.

NMR Sample Preparation-NMR spectra were recorded from two samples, which contained either $0.5 \mathrm{mM}{ }^{15} \mathrm{~N}$-labeled or $1 \mathrm{mM}{ }^{15} \mathrm{~N} /{ }^{13} \mathrm{C}$ labeled Conk-S1 in $0.1 \mathrm{~m}$ sodium acetate buffer, $\mathrm{pH} 5.2$, with $10 \%{ }^{2} \mathrm{H}_{2} \mathrm{O}$. Dipolar couplings were measured from an anisotropic sample, in which the peptide was partially aligned. It contained $0.5 \mathrm{~mm}{ }^{15} \mathrm{~N} /{ }^{13} \mathrm{C}$-labeled Conk-S1 in $85.5 \% 0.1$ m sodium acetate buffer, $\mathrm{pH} 5.2,9.5 \%{ }^{2} \mathrm{H}_{2} \mathrm{O}, 4.3 \%$ pentaethylene glycol monododecyl ether $\left(\mathrm{C}_{12} \mathrm{E}_{5}\right)$, and $0.7 \%$-hexanol. The nematic phase was formed after vigorous mixing (8).

NMR Resonance Assignment and Structure Calculation-All spectra were recorded at $27^{\circ} \mathrm{C}$ on Bruker $600,700,800$, or $900 \mathrm{MHz}$ spectrometers equipped with shielded gradient triple resonance probes. For the backbone and side chain assignment the standard heteronuclear $\left({ }^{1} \mathrm{H}\right.$, ${ }^{13} \mathrm{C},{ }^{15} \mathrm{~N}$ ) strategy based on three-dimensional HNCACB, CBCA(CO)NH, HNCO, HN(CA)CO, HCCNH-TOCSY, CCONH-TOCSY, and HCCH-TOCSY experiments was used (9). The backbone resonance assignment was achieved automatically with the assignment program MARS (10). ${ }^{3} J_{\mathrm{HN}-\mathrm{HA}}$ coupling constants were obtained using two-dimensional CT-HMQC-J spectra and were converted to $\Phi$ torsion angles with the empirical Karplus equation (11). $\chi_{1}$ torsion angles were gained from two-dimensional HNCG spectra (12). The program TALOS was used to obtain the backbone dihedral angles $(\Phi$ and $\Psi$ ) on the basis of chemical shift information (13). Interproton distance restraints were derived from three-dimensional ${ }^{15} \mathrm{~N}$-edited NOESY (120 ms mixing time) and ${ }^{13} \mathrm{C}$-edited NOESY spectra (128 ms mixing time). The NMR data were processed and analyzed using NMRPipe, NMRDraw (14), and SPARKY. ${ }^{3}$

The NOE spectra were automatically peak picked and integrated with SPARKY. NOE cross-peaks were assigned both manually and automatically by the programs ARIA2alpha (15) and CYANA (16). Unambiguous cross-peak assignments with a range of 1.8 to $5 \AA$ set by CYANA were used for the final structure calculations.

Residual ${ }^{1} D_{\mathrm{N}-\mathrm{H}},{ }^{1} D_{\mathrm{CA}-\mathrm{HA}},{ }^{1} D_{\mathrm{N}-\mathrm{C}}$, and ${ }^{1} D_{\mathrm{C}-\mathrm{CA}}$ dipolar couplings were gained from the difference between the $J$ couplings measured in the aligned and isotropic media. ${ }^{1} J_{\mathrm{N}-\mathrm{H}}$ and ${ }^{1} J_{\mathrm{N}-\mathrm{C}}$ couplings were measured simultaneously from interleaved three-dimensional TROSY-HNCO

${ }^{3}$ T. D. Goddard and D. G. Kneller, SPARKY 3, University of California, San Francisco, CA. spectra and ${ }^{1} J_{\mathrm{CA}-\mathrm{HA}}$ and ${ }^{1} J_{\mathrm{CA}-\mathrm{C}}$ were obtained simultaneously from interleaved three-dimensional CBCA $(\mathrm{CO}) \mathrm{NH}$ spectra. ${ }^{4}$ The magnitude (normalized to ${ }^{1} D_{\mathrm{N}-\mathrm{H}}$ ) and rhombicity of the alignment tensor were 13.0 $\mathrm{Hz}$ and 0.38 , respectively, as determined from the histogram of dipolar couplings by the program PALES (17).

Initially, a medium resolution structure was calculated with the program Rosetta NMR (18) based on dipolar couplings and chemical shift information and applying the ITAS approach (19). This structure was used as a starting point for calculation of a high-resolution structure using either CNS Solve 1.1 (20), interfaced with ARIA2alpha or CYANA 2.0.32. Finally a simulated annealing protocol with 7 iterations were performed with CYANA. In the last a total of 20 structures were calculated. The 20 structures were further refined in explicit water (21) and were used for the statistics. A total of 551 NOEs, 365 of them short range $(|i-j| \leq 1), 73$ medium range $(1<|i-j|<5)$, and 113 long range $(|i-j| \geq 5)$ NOEs, 201 dipolar couplings, 126 dihedral angles, and two disulfide bridge constraints were used in structure calculations.

Electrophysiological Measurements-To study the effects of the wild type and mutants of Conk-S1 with the Shaker potassium channel the Xenopus oocyte expression system was used. Oocyte preparation and Shaker RNA injection were performed as described by Jacobsen et al. (22). Whole-cell currents were recorded under two-electrode voltage clamp control using a Turbo-Tec amplifier (NPI Instruments, Tamm, Germany). The intracellular electrodes were filled with $2 \mathrm{~m} \mathrm{KCl}$ and had a resistance between 0.4 and $1 \mathrm{~m} \Omega$. Current records were low-pass filtered at $1 \mathrm{KHz}(-3 \mathrm{db})$ and sampled at $4 \mathrm{kHz}$. The bath solution was normal frog Ringer's containing $115 \mathrm{~mm} \mathrm{NaCl}, 2.5 \mathrm{~mm} \mathrm{KCl}, 1.8 \mathrm{~mm}$ $\mathrm{CaCl}_{2}$, and $10 \mathrm{~mm}$ Hepes, $\mathrm{pH} 7.2(\mathrm{NaOH})$. All electrophysiological experiments were performed at room temperature $\left(19-22^{\circ} \mathrm{C}\right)$. Toxincontaining solutions were applied continuously during the whole experiment from a reservoir through a silicon tube directly into the bath chamber. Whole-cell currents at a test potential of $0 \mathrm{mV}$ were measured every $15 \mathrm{~s}$ during toxin application.

The $\mathrm{IC}_{50}$ values of Conk-S1 and of Conk-S1 ${ }^{\mathrm{CC}}$ were calculated from the reduction of whole-cell currents at a test potential of $0 \mathrm{mV}$ obtained from oocytes expressing Shaker potassium channel according to the relationship $\mathrm{IC}_{50}=f c /(1-f c)[T x]$, where $\mathrm{fc}$ is the fractional current and $[T x]$ is the toxin concentration. Data are given as means \pm the standard deviation (r.m.s.d.).

The $k_{\text {on }}$ and $k_{\text {off }}$ values were obtained by an exponential fit [ $y=y_{0}+$ $\left.\mathrm{A}^{*} \exp \left(-k^{*} x\right)\right]$ to the experimental data during decrease and increase of the current, obtained during the wash-in and wash-out of the peptide. This is possible because the "on" reaction is pseudo first order, due to the constant toxin concentration, and the "off" reaction is first order.

\section{RESULTS}

Resonance Assignment and Tertiary Structure-The ${ }^{15} \mathrm{~N}$ HSQC of Conk-S1 displayed an excellent chemical shift dispersion indicative of a well folded, rigid protein (data not shown). Backbone resonances for all residues except $\mathrm{Gly}^{39}$ and $\mathrm{Tyr}^{51}$ could be identified in the ${ }^{15} \mathrm{~N}$ HSQC spectrum. In total $96.97 \%$ of the backbone resonances and $91.63 \%$ of the side chain chemical shifts have been assigned. The superposition of the 20 structures with the lowest total energy is shown in Fig. 1. The quality of the solution structures is summarized in supplemental Table 1. In the Ramachandran plot $88.2 \%$ of the dihedral angles appear in the most favorable region and $9.8 \%$ in the additionally allowed region. For all heavy atoms the root mean square deviation to the mean structure is $1.4 \AA$, and for the

${ }^{4}$ Vijayan, V., and Zweckstetter, M. (2005) J. Magn. Reson. 174, $245-253$ 

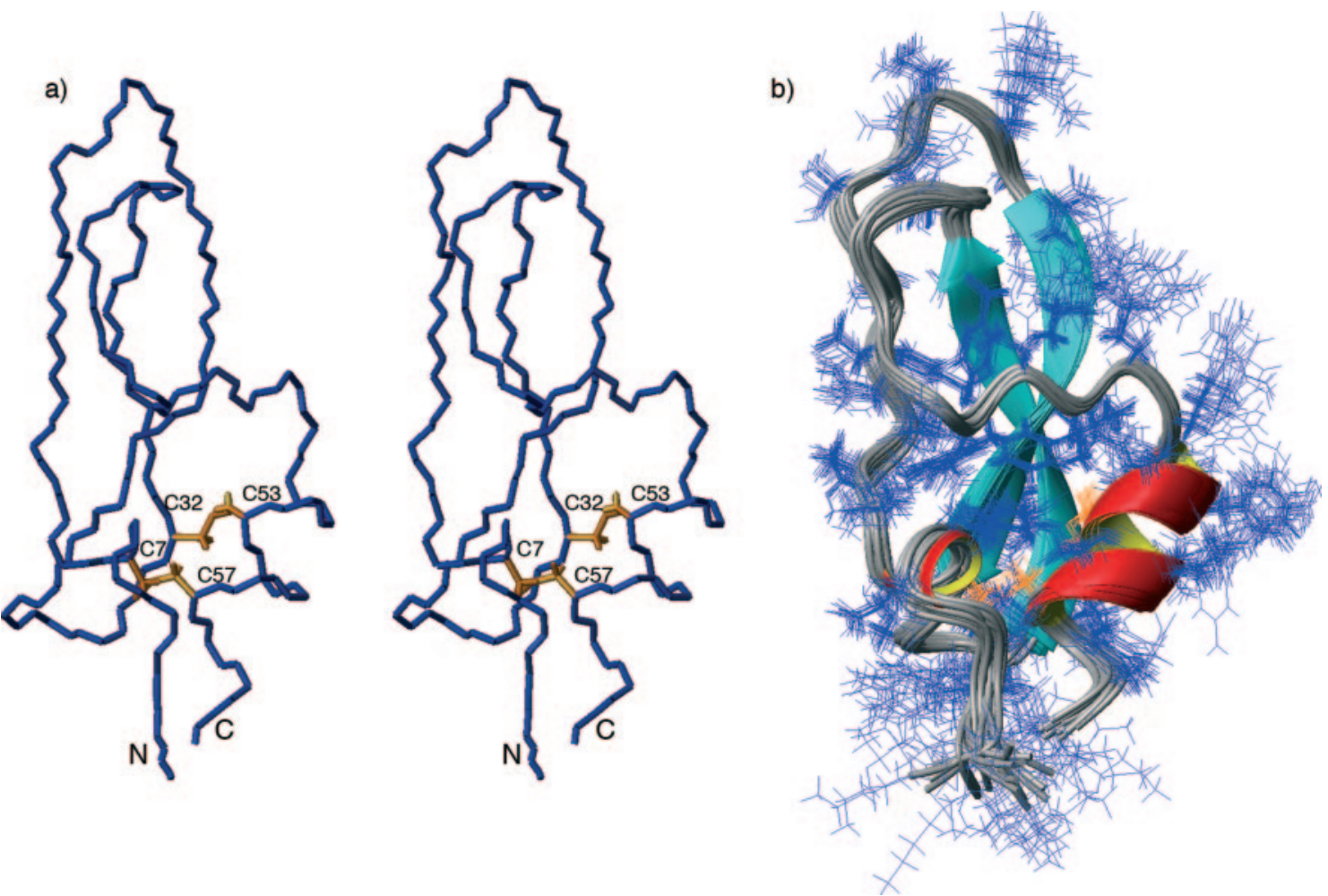

FIG. 1. NMR solution structures of Conk-S1. $a$, stereo view of the backbone atoms $\left(\mathrm{N}, \mathrm{C}^{\alpha}, \mathrm{C}, \mathrm{O}\right)$. Represented is the mean structure of the 20 structures with lowest total energy. Cysteine bidges are marked in orange. $b$, superposition of the 20 structures with lowest total energy. A ribbon presentation of the backbone, including side chains, represented as lines, is shown. Helices are marked in red and $\beta$-strands in cyan. All figures were created with the program MOLMOL (29).

backbone atoms it is $0.7 \AA$. Side chains are well defined, as can be seen from Fig. $1 b$.

Steady state heteronuclear ${ }^{15} \mathrm{~N}\left\{{ }^{1} \mathrm{H}\right\}$ NOEs for most of the Conk-S1 backbone amides are above 0.6 indicating that the backbone of Conk-S1 is well ordered in solution (data not shown). Only $\mathrm{Thr}^{60}$ and $\mathrm{Ala}^{19}$ are flexible with ${ }^{15} \mathrm{~N}\left\{{ }^{1} \mathrm{H}\right\} \mathrm{NOE}$ values of 0.22 and 0.15 , respectively, and the three $\mathrm{N}$-terminal residues are affected by motion. Ala ${ }^{19}$ is located in the region homologous to the antiprotease loop of BPTI and is close to the "missing" third disulfide bond, which would be between the position $\mathrm{Gly}^{16}$ and $\mathrm{Gln}^{40}$.

The solution structure of Conk-S1 resembles the typical Kunitz-type fold. It consists of a $3_{10}$-helix of residues $6-8$, a twisted $\beta$-hairpin of residues $20-36$, and an $\alpha$-helix of residues $50-56$. The two helices are connected by the disulfide bridge between $\mathrm{Cys}^{7}$ and $\mathrm{Cys}^{57}$. The $\mathrm{C}$-terminal helix is also connected to the $\beta$-sheet by the disulfide bridge between $\mathrm{Cys}^{32}$ and $\mathrm{Cys}^{53}$. The disulfide bridge 7-57 was confirmed by four direct NOE contacts between these residues. For the other S-S pairing no direct contact could be observed. In this case NOEs between $\mathrm{Cys}^{32}$ and $\mathrm{Gln}^{54}$, and other long range NOEs between residues close to the cysteines were used to confirm the cysteine bridge.

To verify that the disulfide bonds were actually formed, electrospray quadrupole mass spectra were recorded. The theoretical masses of Conk-S1 and Conk-S1 ${ }^{\mathrm{CC}}$ without disulfide bridge formation would be 6933.6 and $6954.7 \mathrm{Da}$, respectively. The masses measured for Conk-S1 and Conk-S1 ${ }^{\mathrm{CC}}$ were $6929.3 \pm 0.8 \mathrm{Da}$ and $6948.2 \pm 0.9 \mathrm{Da}$, consistent with the formation of two disulfide bonds in the wild type and three disulfide bonds in the mutant Conk-S1.

Functional Characterization with Voltage Clamp Experiments-Since the recombinant Conk-S1 does not contain the amidated $\mathrm{C}$ terminus observed in the native peptide, the affinity of the recombinant peptide on Shaker potassium channels expressed in Xenopus oocytes was measured. The functionality of the Conk-S1 with the free acid at the $\mathrm{C}$ terminus was assayed by two-electrode voltage clamp measurements. For these experiments the Shaker potassium channel with removed Nterminal inactivation (Shaker- $\Delta 6-46$ ) was used. Fig. 2 shows that this channel was blocked by Conk-S1 with an $\mathrm{IC}_{50}$ value of $502 \pm 140 \mathrm{~nm}(n=3)$. Since it has been reported that $\kappa$-conotoxin PVIIA and $\kappa \mathrm{M}$-conotoxin RIIIK, which are both also blocking Shaker potassium channels, showed an increase in affinity when tested on a are pore mutant of this channel (K427D), the functional effects of Conk-S1 on this mutated Shaker channel was also investigated. Most interestingly the affinity of Conk-S1 for this mutant was $0.22 \pm 0.08 \mathrm{~nm}(n=4)$, which is more than 2000-fold higher than for the wild type channel (see Fig. 2). This result indicates that Conk-S1 blocks potassium channels by interacting with the ion channel pore. Furthermore it underscores the importance of residue 427, located in the outer vestibule of the ion permeation pathway, for the binding of different conotoxins to potassium channels.

All Kunitz domain proteins functionally analyzed so far contain three disulfide bridges. To evaluate the importance of the "missing" disulfide bridge in Conk-S1 a double cysteine mutant $\left(\mathrm{Conk}-\mathrm{S}^{\mathrm{CC}}\right.$ ) carrying an additional cysteine bridge between the positions 16 and 40 was constructed and the activity of this peptide on potassium channels was measured. Most interestingly the affinity of Conk-S1 ${ }^{\mathrm{CC}}$ to Shaker- $\Delta 6-46$ was $385 \pm 58$ $\mathrm{nM}(n=3)$ showing that within the accuracy of measurements wild type and mutant Conk-S1 displayed the same inhibitory potential for Shaker channels. In addition, the affinity of Conk$\mathrm{S} 1^{\mathrm{CC}}$ to Shaker- $\Delta 6-46 \mathrm{~K} 427 \mathrm{D}$ channels is $0.22 \pm 0.05 \mathrm{~nm}(n=$ 3 , which is also identical to the binding affinity of Conk-S1 to this channel mutant. Therefore, for both the wild type sequence and Conk-S1 ${ }^{\mathrm{CC}}$ an increase in affinity by a factor of $\sim 2000$ is observed. For Conk-S1 and Conk-S1 ${ }^{\mathrm{CC}}$ dose response measurements with the wild type and K427D potassium channels were performed as well, resulting in almost identical $\mathrm{IC}_{50}$ values (see 
a)

Conk-S1

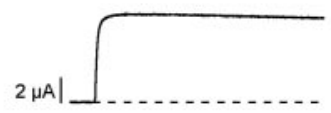

Shaker- $\Delta$
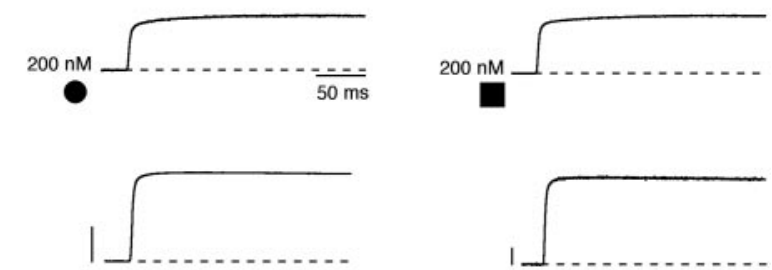

Shaker- $\Delta$
K427D
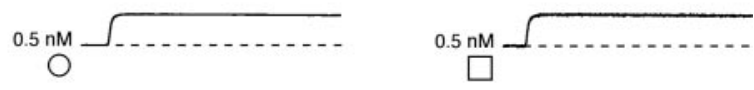

b)

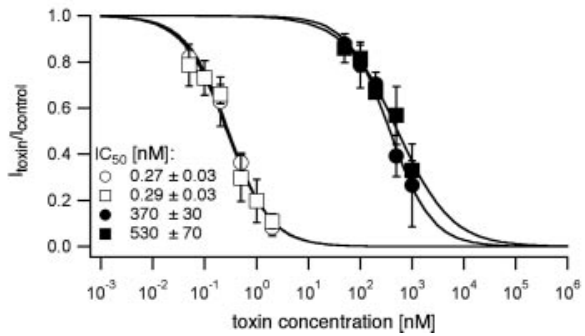

Fig. 2. $a$, whole cell currents upon depolarizing from -100 to $0 \mathrm{mV}$ are shown before and after toxin application. Currents were recorded from oocytes expressing either wild type or K427D Shaker- $\Delta 6-46$ channel. The corresponding channel is indicated beside, and the corresponding toxin above, the curves. The toxin concentration is shown next to the curve, which was recorded after toxin application. The vertical bars represent $2 \mu \mathrm{A} . b$, dose-response curves of wild type (filled symbols) and K427D (open symbols) Shaker- 6 -46 channels. Currents were blocked by Conk-S1 (circles) and Conk-S1 ${ }^{\mathrm{CC}}$ (squares). The symbols are also shown in $a$ at the corresponding toxin/channel combination. The test potential was $0 \mathrm{mV}$, and $n$ was between 2 and 5 for the different toxin concentrations.

Fig. 2). The Hill coefficients for the block of both channels by both peptides were all about 1 , indicating no cooperativity for the binding of both peptides to the channels.

The kinetic analysis of the block of Shaker channels by Conk-S1 and Conk-S1 ${ }^{\mathrm{CC}}$ resulted in $k_{\text {on }}$ values (for the forth reaction) of $17 \pm 5 \mathrm{~s}^{-1} \mu \mathrm{M}^{-1}$ for Conk-S1 and $7 \pm 3 \mathrm{~s}^{-1} \mu \mathrm{M}^{-1}$ for Conk-S1 ${ }^{\mathrm{CC}}$. The $k_{\text {off }}$ values (for the back reaction) were $0.0041 \pm 0.0006 \mathrm{~s}^{-1}$ for Conk-S1 and $0.0029 \pm 0.0023 \mathrm{~s}^{-1}$ for Conk-S1 ${ }^{\mathrm{CC}}$. This analysis revealed that although the steady state affinity of Conk-S1 and Conk-S1 ${ }^{\mathrm{CC}}$ is virtually identical there are some differences in the kinetics of binding of both peptides to the ion channel.

\section{DISCUSSION}

In this work, we solved the structure of a Kunitz domain polypeptide toxin from the venom of the fish-hunting cone snail, C. striatus. Proteins with Kunitz domains can be divided into two general classes: the "heterogeneous Kunitz domaincontaining proteins," with one or more Kunitz domains, but in combination with other structural motifs, and the "homogeneous Kunitz domain polypeptides" (which we have referred to above simply as "Kunitz domain proteins") that are exclusively composed of Kunitz domains. Such polypeptides may contain one or more Kunitz domains but have no other domain motifs. Conkunitzin-S1 clearly belongs to the latter class.

Conkunitzin-S1 is the first natural Kunitz domain protein with only two disulfide bonds (all other natural Kunitz domain proteins such as BPTI or the dendrotoxins have three disulfide cross-links). Only among the heterogeneous Kunitz domaincontaining proteins Kunitz domains with only two disulfides have been reported (the trophoblast Kunitz domain proteins (23)). These appear to function as protease inhibitors, and their structure has not been solved.

We have demonstrated that, despite containing only two cysteine bridges, the structure of Conk-S1 is very similar to that of other Kunitz domain peptides like BPTI (backbone $\mathrm{C}^{\alpha}$ r.m.s.d. = $1.3 \AA$ ) and the dendrotoxins (backbone $\mathrm{C}^{\alpha}$ r.m.s.d. to dendrotoxin $\mathrm{I}=2.2 \AA$ ).

Comparison of Conk-S1 with BPTI and Dendrotoxins Structures-Native BPTI with three disulfide bonds is extremely stable. It has been demonstrated that removing any one of these cysteine bridges still results in the native conformation, which is stable under normal conditions (24). The most productive BPTI folding pathway includes a cysteine bridge rearrangement of non-native disulfide intermediates. This rearrangement facilitates the folding process under most experimental conditions. The most important of these intermediates of BPTI are $\mathrm{Cys}^{30}-\mathrm{Cys}^{51}, \mathrm{Cys}^{5}-\mathrm{Cys}^{14}$ and $\mathrm{Cys}^{30}-\mathrm{Cys}^{51}$, $\mathrm{Cys}^{5}-\mathrm{Cys}^{38}$ (25). This folding pathway is not possible for Conk-S1 because the cysteines 14 and 38 (corresponding to 16 and 40 in Conk-S1) are replaced by glycine and glutamine, respectively. The folding of dendrotoxin I and dendrotoxin $\mathrm{K}$ uses similar folding pathways as BPTI but with important energetic and kinetic differences. In particular, a direct pathway, without disulfide rearrangements, is significantly more populated than in BPTI folding (24). The existence of a native Kunitz domain with two replaced cysteines, as determined in this study, confirms that non-native disulfide intermediates are not necessary for the folding of Kunitz domains. This is also consistent with other studies, where mutants of BPTI, which lack $\mathrm{Cys}^{14}$ and $\mathrm{Cys}^{38}$, still folded properly (26). Another mutant of BPTI with only two disulfide bridges $\left(\mathrm{Cys}^{30}-\mathrm{Cys}^{51}, \mathrm{Cys}^{14}\right.$ $\mathrm{Cys}^{38}$ ) also shows a native fold, while the corresponding mutant in dendrotoxin $\mathrm{K}$ is only partly folded. This is due to the generally lower stability of dendrotoxins compared with BPTI (24). Conk-S1 is structurally and functionally similar to the dendrotoxins. Considering the compromised folding of cysteine mutants in dendrotoxins, it is surprising that Conk-S1 still attains the typical Kunitz fold.

Functionality of Conk-S1-Recently it has been shown that the native, C-terminally amidated Conk-S1 blocks Shaker potassium channels with an $\mathrm{IC}_{50}$ of about 60 nM. ${ }^{2}$ In our study a recombinant Conk-S1 has been used, which is lacking the Cterminal amidation. The functional consequence of this difference was studied by measuring the affinity of the recombinant Conk-S1 on Shaker- $\Delta 6-46$ channels expressed in Xenopus oocytes. The $\mathrm{IC}_{50}$ value of the recombinant Conk-S1 used in this study is 6-7 times higher than that of the native Conk-S1, indicating a reduced inhibitory potential of the recombinant toxin. Despite this contribution of C-terminal amidation of Conk-S1 for potassium channel inhibition, our results demonstrate that recombinant Conk-S1 is functional. This provided the opportunity to use this recombinant neurotoxin for investigating structure, dynamics, electrophysiological properties, and the effects of mutations.

Most interestingly the electrophysiological measurements revealed that there is no difference in the affinity between Conk-S1 with two disulfide bonds and the three-disulfidebonded mutant Conk-S1 ${ }^{\mathrm{CC}}$. Furthermore, both peptides exhibit an $\sim 2000$ fold higher affinity to the K427D mutant of the Shaker potassium channel than to the wild type channel. This demonstrates clearly the importance of the region around residue Lys $^{427}$ in Shaker potassium channel for the binding to Conk-S1 and indicates that Conk-S1 is interacting with the 
pore region of the ion channel. In addition, it suggests that the missing cysteine bridge is not of critical functional importance for the block of the potassium channel by Conk-S1.

Despite the identical steady state values, the kinetic analysis revealed some differences in the binding of both toxin analogues. The $k_{\text {on }}$ and the $k_{\text {off }}$ values for Conk-S1 were approximately two times higher than for Conk-S1 ${ }^{\mathrm{CC}}$. Thus, Conk-S1 binds twice as fast to the channel as Conk-S1 $1^{\mathrm{CC}}$, but it is also released twice as fast from its binding site. Therefore, the two effects compensate, resulting in identical $\mathrm{IC}_{50}$ values of Conk-S1 and Conk-S1 ${ }^{\mathrm{CC}}$. From the kinetic point of view, this indicates that for Conk-S1 ${ }^{\mathrm{CC}}$ the formation of the complex with the channel as well as the dissociation of this complex might have a higher energy barrier. This is likely related to the number of disulfide bonds; the additional cysteine bridge makes Conk-S1 ${ }^{\mathrm{CC}}$ more rigid. For binding of the toxin to the channel, flexibility within Conk-S1 may enhance the rate of binding to the channel by allowing the toxin to adjust more easily into the binding pocket within the ion channel pore.

Interestingly, experiments with dendrotoxins resulted in the reverse situation (27). When the disulfide bond homologous to the missing third disulfide bond of Conk-S $1^{\text {cc }}$ was selectively removed from dendrotoxins $\mathrm{I}$ and $\mathrm{K}$ with iodoacetamide, derivatized dendrotoxins showed a 5-10 times lower affinity than the unmodified toxins. One possible explanation for this effect could be steric hindrance by the acetamide group. On the other hand, the different results obtained for dendrotoxins and Conk-S1 may indicate a different binding mode of Conk-S1 and dendrotoxins, even though these peptides both target voltagegated potassium channels. In another report it was shown that by selectively reducing the cysteine bridge in BPTI, which is homologous to the one introduced into Conk-S1 ${ }^{\mathrm{CC}}$, with borohydride, no change in activity was observed (28). Therefore, Conk-S1 more closely resembles BPTI than the dendrotoxins with respect to the importance of this disulfide bond for the functional activity of the protein.

In conclusion, we have determined the structure of Conk-S1, an unusual potassium channel-targeted toxin that has a consensus Kunitz domain amino acid sequence but which lacks one of the three disulfide bonds that are conserved in all natural Kunitz domain peptides characterized to date. The structure does not strongly diverge from those of standard Kunitz domains with three disulfide bonds. A Conk-S1 analog with the third disulfide bond had similar potassium channel blocking activity, indistinguishable from that of the native peptide. Both the two- and three-disulfide-cross-linked toxins had much higher affinity for the K427D Shaker potassium channel mutant, suggesting that they interacted equally avidly with the vestibule of the ion channel pore.

Acknowledgments-We are grateful to Prof. C. Griesinger for valuable support and advice. We thank Karin Giller, Annett Sporning, and Petra Widawka for expert technical help.

\section{REFERENCES}

1. Pardi, A., Wagner, G., and Wuthrich, K. (1983) Eur. J. Biochem. 137, 445-454

2. Dreyer, F. (1990) Rev. Physiol. Biochem. Pharmacol. 115, 93-136

3. Vincent, J. P., and Lazdunski, M. (1972) Biochemistry 11, 2967-2977

4. Imredy, J. P., and MacKinnon, R. (2000) J. Mol. Biol. 296, 1283-1294

5. Terlau, H., and Olivera, B. M. (2004) Physiol. Rev. 84, 41-68

6. Craig, A. G., Bandyopadhyay, P., and Olivera, B. M. (1999) Eur. J. Biochem. 264, 271-275

7. Mathys, S., Evans, T. C., Chute, I. C., Wu, H., Chong, S., Benner, J., Liu, X. Q., and Xu, M. Q. (1999) Gene (Amst.) 231, 1-13

8. Ruckert, M., and Otting, G. (2000) J. Am. Chem. Soc. 122, 7793-7797

9. Bax, A., and Grzesiek, S. (1993) Acc. Chem. Res. 26, 542-553

10. Jung, Y. S., and Zweckstetter, M. (2004) J. Biomol. NMR 30, 11-23

11. Pardi, A., Billeter, M., and Wuthrich, K. (1984) J. Mol. Biol. 180, 741-751

12. Hu, J. S., and Bax, A. (1997) J. Biomol. NMR 9, 323-328

13. Cornilescu, G., Delaglio, F., and Bax, A. (1999) J. Biomol. NMR 13, 289-302

14. Delaglio, F., Grzesiek, S., Vuister, G. W., Zhu, G., Pfeifer, J., and Bax, A. (1995) J. Biomol. NMR 6, 277-293

15. Linge, J. P., O’Donoghue, S. I., and Nilges, M. (2001) Methods Enzymol. 339, 71-90

16. Herrmann, T., Guntert, P., and Wuthrich, K. (2002) J. Mol. Biol. 319, 209-227

17. Zweckstetter, M., and Bax, A. (2000) J. Am. Chem. Soc. 122, 3791-3792

18. Simons, K. T., Kooperberg, C., Huang, E., and Baker, D. (1997) J. Mol. Biol. 268, 209-225

19. Jung, Y. S., Sharma, M., and Zweckstetter, M. (2004) Angew Chem. Int. Ed. Engl. 43, 3479-3481

20. Brunger, A. T., Adams, P. D., Clore, G. M., DeLano, W. L., Gros, P., GrosseKunstleve, R. W., Jiang, J. S., Kuszewski, J., Nilges, M., Pannu, N. S., Read, R. J., Rice, L. M., Simonson, T., and Warren, G. L. (1998) Acta Crystallogr. Sect. D Biol. Crystallogr. 54, 905-921

21. Linge, J. P., Williams, M. A., Spronk, C. A., Bonvin, A. M., and Nilges, M. (2003) Proteins 50, 496-506

22. Jacobsen, R. B., Koch, E. D., Lange-Malecki, B., Stocker, M., Verhey, J., Van Wagoner, R. M., Vyazovkina, A., Olivera, B. M., and Terlau, H. (2000) J. Biol. Chem. 275, 24639-24644

23. MacLean, J. A., II, Roberts, R. M., and Green, J. A. (2004) Biol. Reprod. 71, 455-463

24. Kortemme, T., Hollecker, M., Kemmink, J., and Creighton, T. E. (1996) J. Mol. Biol. 257, 188-198

25. van Mierlo, C. P., Kemmink, J., Neuhaus, D., Darby, N. J., and Creighton, T. E. (1994) J. Mol. Biol. 235, 1044-1061

26. Marks, C. B., Naderi, H., Kosen, P. A., Kuntz, I. D., and Anderson, S. (1987) Science 235, 1370-1373

27. Hollecker, M., Marshall, D. L., and Harvey, A. L. (1993) Br. J. Pharmacol. 110, $790-794$

28. Kress, L. F., and Laskowski, M., Sr. (1967) J. Biol. Chem. 242, 4925-4929

29. Koradi, R., Billeter, M., and Wuthrich, K. (1996) J. Mol. Graph 14, 29-32, $51-55$

30. Berndt, K. D., Guntert, P., and Wuthrich, K. (1993) J. Mol. Biol. 234, $735-750$ 